\title{
Interest Rate and Financing of Islamic Banks in Indonesia (A Vector Auto Regression Approach)
}

\author{
Bismi Khalidin ${ }^{1,2}$ \& Raja Masbar ${ }^{3}$ \\ ${ }^{1}$ Department of Islamic Economic Law (HES), State Islamic University (UIN) of Ar-Raniry, Banda Aceh, \\ Indonesia \\ ${ }^{2}$ Member of the Association of Shariah Economic Law Study Program of Indonesia (Aphesi), Indonesia \\ ${ }^{3}$ Professor of Economics, Faculty of Economics and Business, Syiah Kuala University, Banda Aceh, Indonesia \\ Correspondence: Bismi Khalidin, Department of Islamic Economic Law (HES) State Islamic University (UIN) \\ of Ar-Raniry, Banda Aceh, Indonesia. Tel: 628-116-807-255. E-mail: bkhalidin_uin.arraniry@yahoo.com
}

Received: April 26, 2017

Accepted: May 17, 2017

Online Published: June 20, 2017

doi:10.5539/ijef.v9n7p154

URL: https://doi.org/10.5539/ijef.v9n7p154

\begin{abstract}
Not only do commercial banks but also Islamic banks take part towards the economic growth and stability in Indonesia. Islamic banks through the financing services provide sources of fund for investment activities. However, Islamic banks do not employ variable of interest rate in financing activities because it is prohibited in Islam. The banks utilize a profit sharing rate (PSR) system instead. Moreover, the banks must avoid themselves from the influence of interest rate directly or indirectly. This paper aims at exploring the existence of interest rate towards the financing of the Indonesian Islamic banks. By using the VAR method and monthly-based time series data from 2009-2015, interest rate represented by commercial banking rates for consumption $\left(\mathrm{CBR}_{\mathrm{c}}\right)$ and for working capital $\left(\mathrm{CBR}_{\mathrm{wc}}\right)$, the research result indicates that the Islamic banks' financing in Indonesia is indirectly influenced by interest rate. Both the Granger causality and the Pearson correlation tests show that the financing correlate significantly with the rate. The correlation between them is also proved by Impulse Response Function (IRF).
\end{abstract}

Keywords: financing, Islamic banks and interest rate

\section{Introduction}

It is widely acceptable that the banking sector plays an important role for economic development programs. The sector determines an economic growth and stability as well. Moreover, based upon experiences in a number of countries throughout the world, economic and financial crises attacking those countries usually start with the collapse of banking sector. Likewise, a good banking sector habitually will creates stabilities in the economy of a country. This is because that the sector is the important part of financial market to which plays an essential role towards the economy.

Islamic banks are part of the banking sector. The banks, with respect to the roles towards the economy, perform tasks and responsibilities of banking as commercial banks do. Indonesia, for instance, currently the Islamic banks in the country start to be as the alternative sources of fund for investment. Investment products provided by the banks are not only for Muslims but also for others, which means that the banks are serving for all types of population, such as native people, aliens, Muslims or others. In the other word, non-Muslim costumers also participate in the Indonesian Islamic banking industry, including in financing-related activities in particular.

However, financing products and activities under an Islamic banking system must be free from interest rate directly or indirectly. Moreover, free-interest is a specific characteristic of Islamic banking, which is also regarded as the core differentiation with its counterpart, commercial or conventional banking. According to El-Hawary et al. (2004), two exceptionally important principles of Islamic banking are risk-sharing and no-exploitation. Hence, a fixed return system as part of interest rate is prohibited. The rate is regarded exploitation to the society because regarded as riba, and it is prohibited by the Holy Quran and the Hadith of the Prophet Muhammad (pbuh).

Financing of Islamic banks applies profit-loss sharing (PLS) system instead. Profit Loss Sharing system and paradigm is considered as a unique feature in Islamic banking system (Chong \& Liu, 2009). Islamic Economic 
Scholars argue that equity finance is preferable to interest-based debt finance because if the venture fails, the borrower does not bear the entire cost alone. Also, if the venture succeeds, the financial investor receives a larger return than a predetermined interest rate would allow (Khan, 2010). Currently, however, there are only three Islamic countries adopt the Islamic banking system completely, namely Iran, Pakistan and Sudan, while other countries, such as Malaysia, Egypt, Saudia Arabia and Indonesia, are still dominated by conventional banking institutuions which operate alongside Islamic banks (Aggarwal \& Yousef, 2000).

Nevertheless, it is important to note that interest rate is the core variable in a banking industry. One side, Islamic banks are part of the industry, but, the other side, interest rate is prohibited in the financing under Islamic banking system. And, as known, interest rate is regarded as an ineviTable variable for banking industry where it determines the performance of banks. Can Islamic banks avoid themselves from the involvement of interest rate in financing services? Is it possible Islamic banks free from the influence of the rate? Some experiences of Islamic banks in several Islamic countries indicate the existence of interest rate towards the banks. Kader and Leong's research (2009), for instance, found that the increase of base lending rate will induce customers to get financing services from Islamic banks and vice versa.

In Indonesia, for instance, murabahah financing is viewed by some to be similar with interest-based credits of conventional banks. Moreover, the financing, which is based upon mark-up system, dominates the Islamic banks' financing in the country. Islamic banks, according to the writer, should focus on PLS-based financing instead, because it is regarded as the fundamental feature of Islamic banking. Such the phenomenon also prevails in Islamic banks in the Middle East and Malaysia, where most Islamic banks have shown a widespread preference in murabahah financing rather than other financing products orderred by the banks (Shinsuke, 2007).

How is the Islamic banks' financing in Indonesia, murabahah financing in particular? Is such the financing free from the influence of interest rate directly or indirectly? Is it true that murabahah financing the same as interest-based credits of conventional banks as currently judged by part of Muslim people in Indonesia? They are among questions very essential to be answered and examined. This paper elucidates the financing of Islamic banks in Indonesia, particularly their relationship with interest rate.

\section{Literature Review}

\subsection{Islamic Banking Principles}

Islamic banks are the banks applying Islamic principles within their operation (Khalidin, 2016). They are also known as the banks complying with the Islamic law or shariah, which means that their operations are permissible under shariah. Nienhaus (1983) defines Islamic banks as the financial institutions relying on the principles of profit-loss sharing (PLS) with the entrepreneurial partners in their relevant banking activities. Islamic banking is part of Islamic finance, which is part of Islam (As-Salus, 1998), therefore the underlying foundation of Islamic banking is the Holy Quran and the Hadith of the Prophet Muhammad (pbuh). Bidabad et al. (2011) argue that the financial activities under Islamic economics are based upon the Islamic faith and must stay within the limits of Islamic Law or the Shariah compliant in all aspects.

Neither interest nor sinful activities is among the primary principle of Islamic banking. Actually, there are a number of principles underlined by Islam towards the operation of Islamic banking; however, the both principles are the core ones. Such the principles actually prevail in all economic and business activities under an Islamic Economic system as well. Besides, Risk-sharing is considered as an important principle of financing under Islamic Economic perspectives (El-Hawari et al., 2004). The principle means that all parties who involve in financial transactions must share not only the profit but also the losses. The financial system in Islam is a system in which there are no assets without risk and all the transactions are based on the profit-loss sharing system. (Derbel et al., 2010).

Moreover, interest-free and risk-sharing are regarded as the trade-mark or the specific feature of Islamic banking system. Islamic scholars argue that only two of the financial products of Islamic banking perfectly fulfilling to the interest-free and risk-sharing principles, namely mudharabah and musyarakah financings. Either type of financing is free from the involvement of interest rate and implements a profit-loss sharing system instead. Mudharabah financing is the financing where the bank and entrepreneur contribute in capital and effort respectively. Profit achieved is divided as negotiated as well as losses are burden by them. Musyarakah financing is the jointly financing by the bank and entrepreneur, where the both share in capital and effort. Profit is divided among them so are losses, which are borne by them in proportion to their contribution to the financing (Aggarwal \& Yousef, 2000). 


\subsection{Interest Rate and Profit Sharing Rate}

Interest rate is simply defined as the fee or the rate borrowers must pay to lenders because of using the money (Case, 2012). It is also known as the cost for holding the money during a specific time or period. Interest rate is the primary variable in a banking industry. It indirectly reflects the financial policy of a bank as well. Not only is in financial markets, interest rate is also utilized in capital markets. Moreover, interest rate constitutes the important part of monetary instruments with which monetary authorities determine money supply in the economy.

However, interest rate is excluded in Islamic banking system because it is prohibited under an Islam economic perspective. The prohibition of interest rate is a fundamental differentiation between the Islamic banking system and other banking systems. It is essential to note that variable of interest rate is not prohibited in Islamic banking due to the variable itself, but such the prohibition is because its feature is the same as riba to which clearly banned by the Holy Quran and the Hadith. Notwithstanding still debaTable, the majority of Islamic scholars view that interest rate is similar to riba, therefore they declare the rate is forbidden in all economic and financial activities.

Nonetheless, part of Islamic economic scholars view that interest rate is only prohibited in loans, not in deferred sale contracts. According to them, there are two types of prices for the contracts, the immediate cash price and the deferred price. They argue that interest emerges in markets in the form of the difference between an immediate cash price and a deferred price. Consequently, according to their views, such the interest rate is not only permissible in sale transactions but it is a duty (Al-Masri, 2004)

As as alternative to riba, Profit-Loss Sharing (PLS) based-financing is considered as an ideal mode of financing under Islamic finance (Rahman, 2007). In deposit side, rate of return or known as Profit Sharing Rate (PSR) is defined as the rate how much money will be received by depositors from their deposit in Islamic banks for one year (Anwar \& Watanabe, 2010). In side of financing, profit sharing rate is the rate at which the financiers must pay for banks because of using the fund in any types of financing.

\subsection{Financing in an Islamic Banking System}

The term of financing is actually another name for "credit" in commercial or conventional banking. Because Islamic banking is free from interest rate, the term of credit which is usually used in commercial banking, is replaced by the term of financing. Islamic banking literatures usually use the term "financing" instead of "credit" of commercial banking. Therefore, because of free-interest, the term "credit" is not found in Islamic banks. Technically, however, either financing or credit is the same, in terms of the banks' goals as financial institutions.

As known, demand for credits in commercial banking, either for consumption or investment, is determined by interest rate. In mathematical form, it could be written as the following:

$$
M^{d}=f(i) \quad \text { or } \quad I=f(i)
$$

Because demand for money either for consumption or investment is the same as financing under Islamic banking system, thus, $\mathrm{M}^{\mathrm{d}}$ is replaced by IBFin, and the financing of Islamic banking consist of saveral types of financing, therefore :

$$
M^{d}=\text { IBFin }
$$

According to Khan and Mirakhor (1989), the fundamental feature of financial system in Islam is the unquestionable prohibition of the payment and receipt of interest. Thus, interest rate (i) is not utilized in Islam banking, and instead of interest rate, it employs profit sharing rate as the determinant of financing, the model (1) will be:

$$
\text { IBFin }=f(P S R)
$$

However, for Islamic countries that adopt two banking systems, conventional and Islamic banking, it is assumed that interest rate still influences the banks' financing, in the other word, interest rate is also considered as its determinant. Thus, the model (3) will be :

$$
\text { IBFin }=f(P S R, i)
$$

It is known that banking industries, including Islamic banks, have strong relationship with macroeconomic conditions. In the other word, the amount of deposits saved by the people or financing provided by banks depend upon economic conditions. Hence, economic variables are also considered as the determinants of financing in Islamic banks. If asumed that macroeconomic variables, inflation and economic growth, induce the financing of Islamic banks, the model (4) could be written as the following. 


$$
\text { IBFin }=f(P S R, i, C P I, I P I)
$$

The model (5) above is for examining the total financing of Islamic banks. To examine murabahah financing, which has a specific profit sharing rate, the model is :

$$
\text { Mura }_{\text {fin }}=f\left(P S R_{\text {mura }}, i, C P I, I P I\right)
$$

According to Zuhaily (1985), Murabahah is actually a buying-selling transaction with a basic price and adding a particular profit. Currently, murabahah financing is used dominantly for people's consumption, thus, the financing is assumed to be influenced by conventional banking rate for consumption. Consequently, the model examining murabahah financing will be as the following model :

$$
\text { Mura }_{\text {fin }}=f\left(P S R_{\text {mura }}, C B R_{c}, I M M R, C P I, I P I\right)
$$

where, in case, variable "i" is represented by Inter-Bank Money Market Rate (IMMR). CPI and IPI are Consumer Price Index and Industrial Production Index respectively.

\section{Data and Method}

\subsection{Data}

The monthly-based time series data from 2009 to 2015 are employed in the research. The primary sources of data are from some formal Indonesian institutions, viz. Bank of Indonesia (the Central Bank of Indonesia) and OJK (the Financial Service Authority). In addition, the research employs eight variables, viz. Islamic Bank's Financing in Total (IBFinTot), Murabahah Financing (MuraFin), Profit Sharing Rate of IBFinTot ( PSR $_{\mathrm{ibfintot}}$ ), Profit Sharing Rate of MuraFin ( $\left.\mathrm{PSR}_{\text {murafin }}\right)$, Commercial Banking Rate for consumption $\left(\mathrm{CBR}_{\mathrm{c}}\right)$, Commercial Banking Rate for working capital $\left(\mathrm{CBR}_{\mathrm{wc}}\right)$, Interbank Money Market Rate (IMMR), Consumer Price Index (CPI) and Industrial Production Index (IPI).

\subsection{Method}

There are two models employed in the research. The first and the second models are the ones investigating total financing and murabahah financing of Islamic banks respectively. The both models are as follows :

$$
\begin{gathered}
\text { IBFinTot }=f\left(I B D e p T o t, P S R_{\text {ibfintot }}, C B R_{w c}, I M M R, C P I, I P I\right) \\
\text { MuraFin }=f\left(P S R_{\text {murafin }}, C B R_{c}, I M M R, C P I, I P I\right)
\end{gathered}
$$

An econometic method utilized in the research is the Vector Auto Regression (VAR). An general form of VAR could be written as the following (Johnston \& Dinardo, 1997).

$$
y_{t}=m+A_{1} y_{t-1}+A_{2} y_{t-2}+\ldots+A_{p} y_{t-p}+\varepsilon
$$

Besides, considered as part of the method, the research also uses the Impulse Response Function (IRF) and the Varian Decomposition (VDC). The Granger Causality test takes part in the research as well. In addition, the statistical tool of Pearson Correlation test is employed for determining the direction of causality between the variables in the models.

\section{Empirical Results}

\subsection{General Description on Financing in the Indonesian Islamic Banks}

The establishment of Islamic banks in Indonesia formally started in 1991 where Islamic banks are referred to as Shariah banks by Bank of Indonesia (BI), and Bank Muamalat Indonesia (BMI), established in 1992, is regarded as the first shariah commercial bank (Adnan \& Muhammad, 2007). However, some small Islamic banks (rural banks) have existed before the year; they are BPRS Hareukat Lambaro and BPRS Berkah Amal Sejahtera launched in 1991, located in Aceh and Bandung respectively (Khalidin, 2016). Currently, there are three types of Islamic banks in Indonesia, Islamic Commercial Banks (BUS), Islamic Business Units (UUS) and Rural Islamic Banks (BPRS), all of them provide financial services.

Financing activities of the Islamic banks in Indonesia have actually started when the banks operated. Financing-related products were ordered at the times. Nevertheless, types as well as volumes of financing were still limited. Currently, various sorts of financing are applied by the banks. The number of financing of the banks rises significantly year by year as well. Three sorts of financing dominantly utilized by the banks are Mudharabah, Musyarakah and Murabahah. However, the murabahah financing, a mark up-based product, covers about two-third of the total financing, whereas the both former financing, which are regarded as the trade-mark of Islamic banking, are only 30-35 of the total financing. 


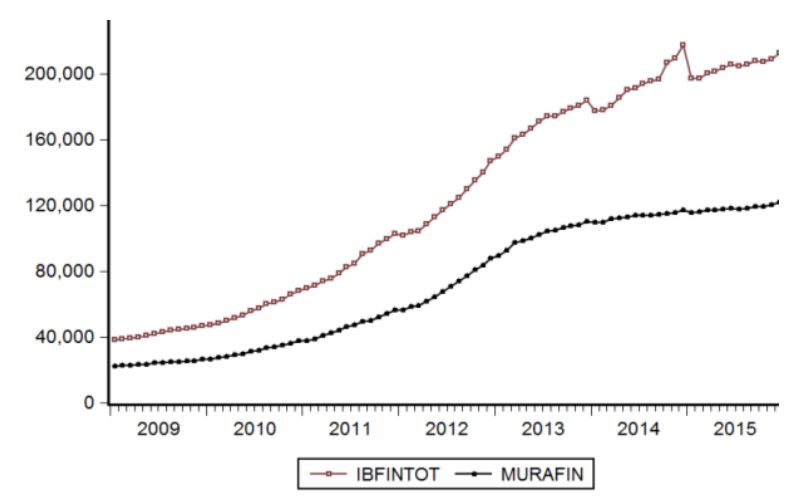

Figure 1. Financing of Islamic banks in Indonesia 2006 to 2015

The Figure 1 denotes that the total financing (the line above) of Islamic banks in Indonesia increased significantly during the last seven years, from 2009 to 2015. Such the total financing consists of several types, such as mudharabah, musyarakah, ijarah and others. The murabahah financing, the line below, as shown by the Figure, also increased significantly during the periods. It is important to note, however, as indicated by the Figure, that the amount of murabahah financing are about two-third of total Islamic banks' financing. The amount of financing is far more than PLS-based ones, mudharabah and musyarakah.

\subsection{Unit Root Test}

A stationarity test is an important step for the VAR method. The method requires that data included in the model must be stationary. The following is ADF and PP unit root test results.

Table 1. Unit root test results

\begin{tabular}{llcccc}
\hline \multirow{2}{*}{ Vo } & Variables & \multicolumn{2}{c}{ ADF Test } & \multicolumn{2}{c}{ PP Test } \\
\cline { 3 - 5 } & & At Level & First Difference & At Level & First Difference \\
\hline 1 & IBFinTot & $-0,1631$ & $-8,9930^{*}$ & $-0,1631$ & $-8,9930^{*}$ \\
2 & MuraFin & $-1,2036$ & $-14,2644 *$ & $-0,2966$ & $-5,9397 *$ \\
3 & IBDepTot & 0,7824 & $-8,6159^{*}$ & 0,7512 & $-8,6626^{*}$ \\
4 & PSRibfintot & $-1,3678$ & $-13,8611^{*}$ & $-1,7613$ & $-13,9859^{*}$ \\
5 & PSRmurafin & $-2,0169$ & $-13,9566^{*}$ & $-2,8370^{* * *}$ & $-3,0414^{* *}$ \\
6 & CBRwc & $-3,0414^{* *}$ & & $-2,6644^{* * *}$ \\
7 & CBRc & $-3,0374 * *$ & & $-3,1883^{* *}$ \\
8 & IMMR & $-3,0183^{* *}$ & & $-9,1029 * *$ \\
9 & CPI & $-9,1029^{*}$ & & $-29,8249^{*}$ \\
10 & IPI & $-7,7827^{*}$ & & & \\
\hline
\end{tabular}

Note. *,** and *** indicate significance levels at $1 \%, 5 \%$ and $10 \%$ respectively.

\subsection{Pearson Correlation Test}

Completed results of the Pearson correlation test on the both models are showed by Table 5 and Table 6 in the appendix. The test is done in order to know causality directions among variables. The Table 5 denotes that all variables included in the first model are significantly correlated, except CPI and IPI, with total financing. In addition, the Table 6 shows that the results are nearly the same with the previous one, in which all variables, except IPI, correlate significantly with murabahah financing.

The Table 5 presents that the total financing of Islamic banks correlates significantly with total deposits (IBDepTot), profit sharing rate (PSR), commercial banking rate for working capital $\left(\mathrm{CBR}_{\mathrm{wc}}\right)$ and Interbank Money Market Rate (IMMR). Nevertheless, CPI and IPI, based upon the Table, are not correlated with the total financing. The former four variables are significant at the 0.01 level (1 percent).

In addition, based upon the correlation results as presented by the Table 6 , three of five exogenous variables are strongly significant at the 0.01 level (1 percent) with murabahah financing. The variables are profit sharing rate of murabahah financing (PSRmurafin), Commercial Banking Rate for consumption $\left(\mathrm{CBR}_{\mathrm{c}}\right)$ and Interbank 
Money Market Rate (IMMR). Customer Price Index (CPI) is also correlated with the financing at the 0.1 level. However, Industrial Production Index (IPI), the variable representing an economic growth, is insignificant correlation at the accepted level of significance with the financing.

\subsection{Granger Causality Test}

The Granger causality test is an important step in the frame of the VAR method. The test is done because the method assumes that all variables in the model are endogenous. Thus, it needs to know the causality among the variables. According to a selected lag, based upon Table 3 and Table 4, the first lag is considered as the optimal lag either for model 1 or for model 2, because statistical criterions indicate the lag. For detail, look at the Table 3 and the Table 4 in the appendix.

Table 2. Granger causality test results

\begin{tabular}{llll}
\hline No & Null Hypothesis & F-Statistic & P-Value \\
\hline 1 & IBDEPTOT does not Granger Cause IBFINTOT & 1.75277 & 0.1893 \\
2 & PSR_IBFINTOT does not Granger Cause IBFINTOT & 3.85923 & $0.0529^{* * *}$ \\
3 & CBR_WC does not Granger Cause IBFINTOT & 9.10262 & $0.0034^{*}$ \\
4 & IMMR does not Granger Cause IBFINTOT & 8.8974 & $0.0038^{*}$ \\
5 & CPI does not Granger Cause IBFINTOT & 0.28922 & 0.5922 \\
6 & IPI does not Granger Cause IBFINTOT & 0.43099 & 0.5134 \\
7 & CBR_WC does not Granger Cause PSRFIN & 5.04222 & $0.0275^{* *}$ \\
8 & PSR_MURAFIN does not Granger Cause MURAFIN & 10.56540 & $0.0017^{*}$ \\
9 & CBR_C does not Granger Cause MURAFIN & 7.72169 & $0.0068^{*}$ \\
10 & IMMR does not Granger Cause MURAFIN & 54.07460 & $1.00 \mathrm{E}-10^{*}$ \\
11 & CPI does not Granger Cause MURAFIN & 0.62529 & 0.4314 \\
12 & IPI does not Granger Cause MURAFIN & 0.31305 & 0.5774 \\
13 & CBR_C does not Granger Cause PSR_MURAFIN & 2.73203 & $0.1023^{*}$ \\
\hline
\end{tabular}

Note. ${ }^{*}, * *$ and $* * *$ indicate significance levels at $1 \%, 5 \%$ and $10 \%$ respectively.

The Table 2 shows that the total financing in the Islamic banks is influenced by interest rates, $\mathrm{CBR}_{\mathrm{wc}}$ and IMMR. This is indicated by the P-Values of the both, which is 0.0034 and 0.0038 respectively, meaning the both types of interest significantly influence the total financing of the Indonesian Islamic banks. In addition to the variables, total financing of the banks is influenced by profit sharing rate of financing, signified by a significant $\mathrm{P}$-value of their correlation. This result is consistent with the result shown by the Person Correlation test. Nevertheless, three other variables, IBDepTot, CPI and IPI are not correlated with the total financing.

Concerning murabahah financing, there are three exogenous variables affecting on the financing, they are $\mathrm{CBR}_{c}$, IMMR and PSR $_{\text {murafin. }}$. The three variables' correlation with murabahah financing is very significant, where their levels of significance are 1 percent. Similar to the total financing, CPI and IPI are not correlated with murabahah financing. The result presented by the Granger Causality test concerning the relationship between murabahah financing and $\mathrm{CBR}_{\mathrm{c}}$, IMMR and $\mathrm{PSR}_{\text {murafin }}$ is in line with the Pearson Correlation test.

Besides, the Table 2 indicates that profit sharing rate either for total financing or for murabahah financing is influenced by interest rate. PSR for total financing and PSR for murabahah financing are influenced by $\mathrm{CBR}_{\mathrm{wc}}$ and $\mathrm{CBR}_{\mathrm{c}}$ respectively. This means that the Islamic banks in determining the profit sharing rate for financing are swayed indirectly by interest rate.

In short, the Granger causality test concludes that the varible of interest has an effect on the financing of Islamic banks in Indonesia. Such the fact is somewhat consistent with the findings of Chong and Liu (2009). They found that the Islamic banks in Malaysia are not very different from their counterpart, conventional banks. In addition, their finding indicates that Islamic deposits are not interest-free.

\subsection{Impulse Response Function}

The following Figure (Figure 2) describes the responses of total financing to interest rate of $\mathrm{CBR}_{\mathrm{wc}}$ and PSR respectively. 

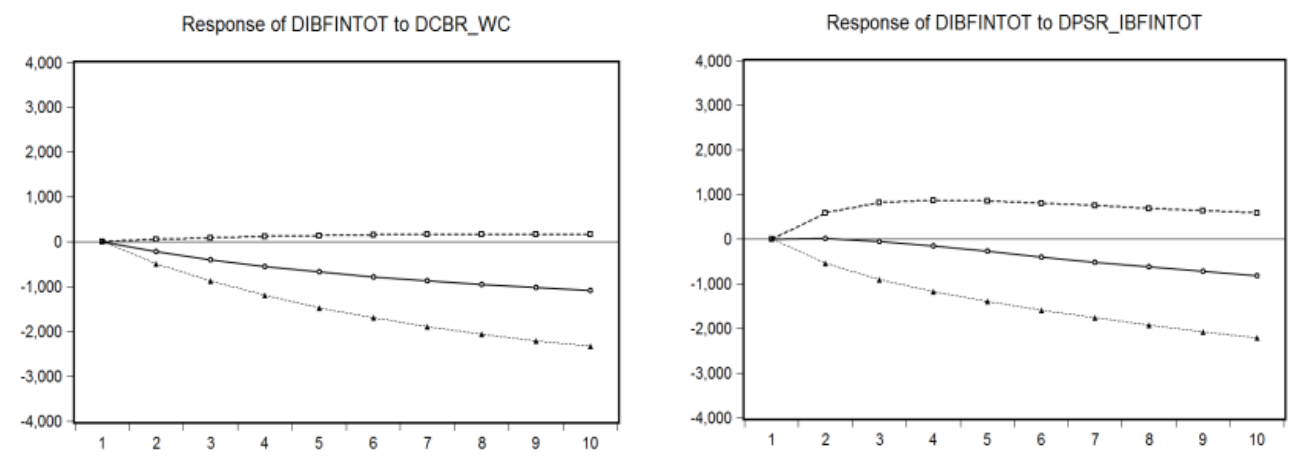

Figure 2. Responses of IBFinTot to $\mathrm{CBR}_{\mathrm{wc}}$ and $\mathrm{PSR}_{\mathrm{ibfintot}}$

The response of total financing to interest rate for working capital $\mathrm{CBR}_{\mathrm{wc}}$, as shown by the left Figure, is immediately and negatively. For detail, the response of total financing to $\mathrm{CBR}_{\mathrm{wc}}$ is presented in the Table 7 in the appendix. The phenomenon displayed by the Figure is consistent with the Granger Causality results, P-Value 0.0038 , indicating a strongly significance of the correlation. A negative correlation between them is confirmed by the Pearson correlation test as well. The Figure discloses that when interest rate increases the amount of financing goes down and vice versa. The same phenomenon also prevails in profit sharing rate of financing. The right Figure reveals that total financing of Islamic banks responds negatively to its PSR, meaning such the PSR determines the total financing.
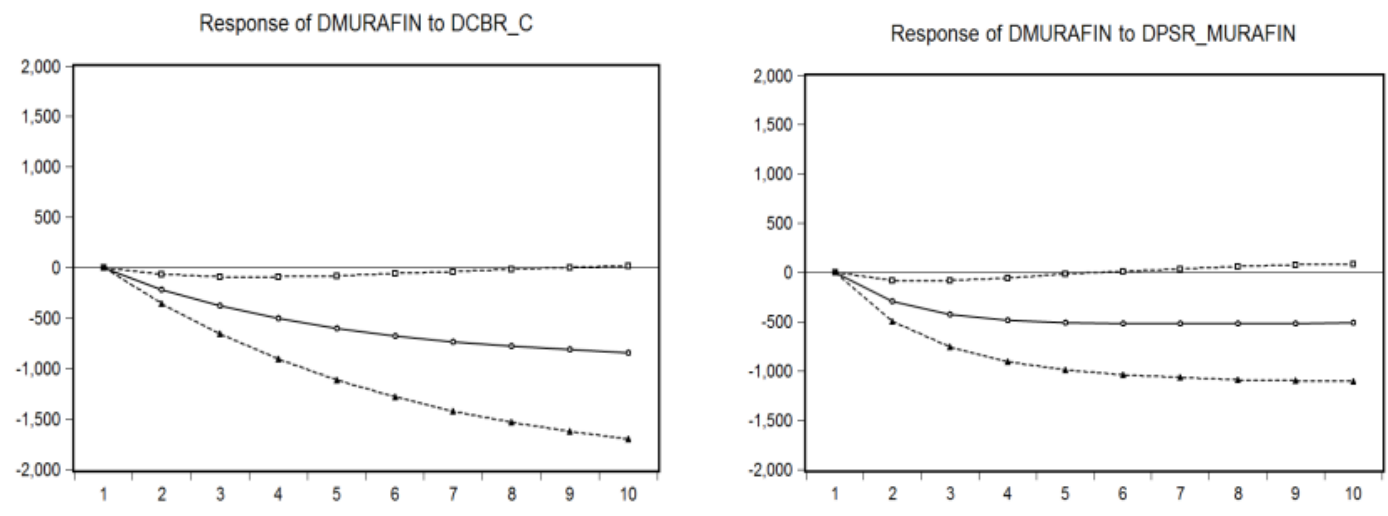

Figure 3. Responses of MuraFin to $\mathrm{CBR}_{\mathrm{c}}$ and $\mathrm{PSR}_{\text {murafin }}$

Similar to the facts described by the Figure 2, murabahah financing responds negatively to both interest rate for consumption $\left(\mathrm{CBR}_{\mathrm{c}}\right)$ and its profit sharing rate $\left(\mathrm{PSR}_{\text {murafin }}\right)$. Table 8 presents the detailed data of the response. The left Figure denotes that there is a negative relationship between murabahah financing and interest rate for consumption. The left Figure presents that as interest rate rises the volume of murabahah financing decreases and vice versa. Besides, the Figure points to that interest rate influences murabahah financing in the Islamic banks in Indonesia.

The same fact also happens in the right one of the Figure 2, describing relationship between murabahah financing and its profit sharing rate. The Figure implies that profit sharing rate (PSR) is a determinant for

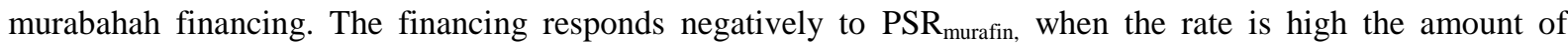
financing reduces. 
Response of DPSR_IBFINTOT to DCBR_WC

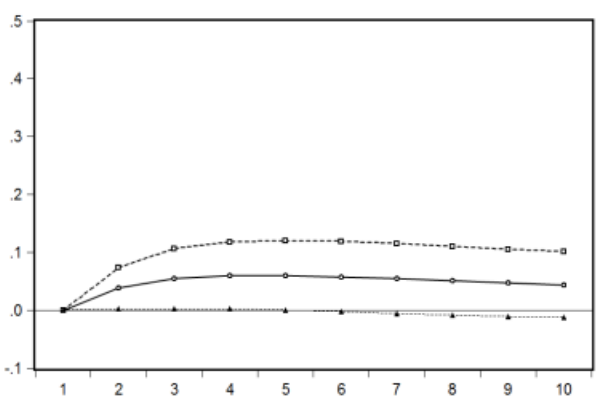

Response of DPSR_MURAFIN to DCBR_C

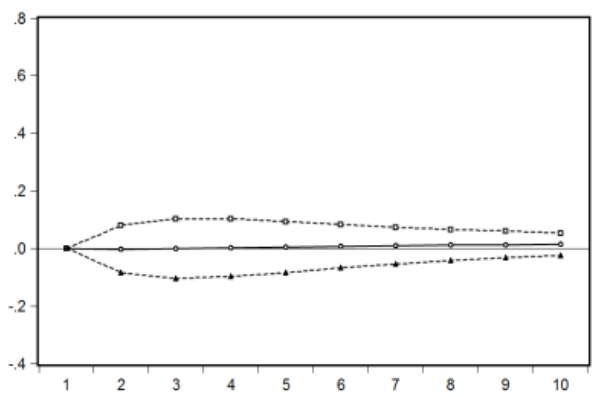

Figure 4. Responses of $\mathrm{PSR}_{\text {ibfintot }}$ to $\mathrm{CBR}_{\mathrm{wc}}$ and $\mathrm{PSR}_{\text {murafin }}$ to $\mathrm{CBR}_{\mathrm{c}}$

Based upon the Granger causality and Pearson correlation tests, profit sharing rate, which is the variable determined by the Islamic banks, correlates with interest rates. In detail, profit sharing rate for total financing $\left(\mathrm{PSR}_{\mathrm{ibfintot}}\right)$ correlates with interest rate for working capital $\left(\mathrm{CBR}_{\mathrm{wc}}\right)$ and profit sharing rate for murabahah financing $\left(\mathrm{PSR}_{\text {murafin }}\right)$ correaltes with interest rate for consumption $\left(\mathrm{CBR}_{\mathrm{c}}\right)$. The Figure 4 corroborates such the facts where it confirms that PSR of financing is influenced by interest rate.

The left Figure shows the fact that there is a positive correlation between profit sharing rate of PSR ibfintot and interest rate of $\mathrm{CBR}_{\mathrm{wc}}$. The Figure demonstrates that the PSR responds positively to interest rate. In the other word, when the interest rate rises the PSR for total financing also grows up and vice versa. Such the reality takes place in the case of murabahah financing as well. However, the response of PSR for murabahah financing to interest rate for consumption $\left(\mathrm{CBR}_{\mathrm{c}}\right)$, as shown by the Figure 4 , is smaller than that of PSR for total financing.

It is essential to be underlined that although the fact that the Islamic banks do not employ interest rate as the yardstick in their financing products, the rate affects such the financing. This is because that the Islamic banks' profit sharing rate correlates with interest rate. In the other word, profit sharing rate of the banks is influenced by interest rate of conventional banks. As interest rate rises, profit sharing rate of Islamic banks goes up and vice versa. Therefore, the fluctuation of interest rate will effect on the amount of financing provided by the Islamic banks.

In general, this research's affirming that there is relationship between interest rate and financing of Islamic banks, is similar to some researches undertaken throughout Islamic countries. One of them is in the Malaysian Islamic banks. Yusoff et al. (2001) find that Islamic and Conventional loan growth of merchant banks are significantly correlation with the growth of overnight Klibor. Moreover, the growth of Islamic loan is more sentitive than that of Conventional one towards the changes in the rate of Klibor.

However, Athari et al. (2016) argue that competition with conventional banks is a serious problem to which Islamic banks are facing now. The banks have to keep their depositors. Thus, Islamic banks are willing to concentrate on mark-up based financing products. Moreover, Islamic banks have to offer higher returns (at least the same) than that of conventional ones.

\section{Conclusion}

The essential feature of Islamic banking regarded as the differentiation with conventional banking is free-interest. The feature is the trade-mark of Islamic banking as well. Moreover, the establishment of Islamic banks throughout the world, including in Indonesia, basically is to avoid from interest-based banking activities. Thus, expected Islamic banks are those free from the influence of interest rate directly or indirectly.

However, this research finds the Islamic banks in Indonesia are not free from the influence of interest rate. In the other word, interest rate indirectly affects on the operation of the banks, particularly in financing. Financing of the banks, total financing or murabahah financing, is influenced by interest rate. Total financing and murabahah financing are affected by interest rate for working capital $\left(\mathrm{CBR}_{\mathrm{wc}}\right)$ and consumption $\left(\mathrm{CBR}_{\mathrm{c}}\right)$ respectively. Both the Pearson correlation and the Granger causality tests conclude that there are correlations among them.

In addition, the research reveals that such the correlation occurs due to PSR of the financing that are affected by interest rate. In the other word, the Indonesian Islamic banks in determining profit sharing rate for financing are influenced by interest rate, either interest rate for working capital or consumption. Therefore, the interest rate indirectly influences upon the number of financing in the Islamic banks in Indonesia. 


\section{References}

Adnan, M. A., \& Muhammad. (2007). Agency Problems in Murabahah Financing: The Case of Sharia (Rural) Banks Indonesia. IIUM Journal of Economics and Management, 15(2), 219-243.

Aggarwal, R. K., \& Yousef, T. (2000). Islamic Banks and Investment Financing. Journal of Money, Credit and Banking, 32(1), 93-120. https://doi.org/10.2307/2601094

Ahmad, A. U., \& Hassan, M. K. (2015). Riba and Islamic Banking. Journal of Islamic Economics, Banking and Finance, 1-33.

Al-Masri, R. Y. (2004). Are All Forms of Interest Prohibited? J.KAU: Islamic Econ., 17(1), 37-41.

Anwar, S., \& Watanabe, K. (2010). Predicting Future Depositor`s Rate of Return Applying Neural Network: A Case-study of Indonesian Islamic Bank. International Journal of Economics and Finance, 2(3), 170-176. https://doi.org/10.2307/2601094

As-Salus, A. A. (1998). Al-Iqtishadul Islamy wal Qadhaya Al Fiqhiyyah Al Muashirah (Vol. 1). Bairut: Muassisah Ar-Rayyan.

Athari, S. A., Adaoglu, C., \& Bektas, E. (2016). Investor protection and dividend policy: The case of Islamic and $\begin{array}{lllll}\text { conventional banks. } & \text { Emerging }\end{array}$ http://dx.doi.org/10.1016/j.ememar.2016.04.001

Bidabad, B., Hassan, A., Ali, M. S., \& Allahyarifard, M. (2011). Interest-Free Bonds and Central Banking Monetary Instruments. International Journal of Economics and Finance, 3(3), 234-241. http://dx.doi.org/10.5539/ijef.v3n3p234

Case, K. E., Fair, R. C., \& Oster, S. M. (2012). Principles of Macroeconomics. Boston, USA: Prentice Hall.

Chong, B. S., \& Liu, M. H. (2009). Islamic Banking: Interest-Free or Interest-Based? Pacific-Basin Finance Journal, 17, 125-144. https://doi.org/10.1016/j.pacfin.2007.12.003

Derbel, H., Bouraoui, T., \& Dammak, N. (2011). Can Islamic Finance Constitute A Solution to Crisis? International Journal of Economics and Finance, 3(3), 75-83. https://doi.org/10.5539/ijef.v3n3p75

El Hawary, D., Grais, W., \& Iqbal, Z. (2004). Regulating Islamic financial institutions: The nature of the regulated. Wold Bank Policy Research Working Paper \#3227. https://doi.org/10.1596/1813-9450-3227

Johnston, J., \& Dinardo, J. (1997). Econometric Methods. McGraw-Hill Companies.

Kader, R. A., \& Leong, Y. K. (2009). The Impact of Interest Rate Changes on Islamic Bank Financing. International Review of Business Research Papers, 5(3), 189-201.

Khalidin, B. (2016). The Impact of Interest Rate towards the Performance of Islamic Banks in Indonesia (Analysis of the Islamic Bank's Operation under Islamic Economic Perspectives). PhD Thesis, Syiah Kuala University, Indonesia.

Khan, F. (2010). How 'Islamic' is Islamic Banking? Journal of Economic Behavior \& Organization, 76, 805-820. http://dx.doi.org/10.1016/ j.jebo.2010.09.015

Khan, M. S., \& Mirakhor, A. (1989). The Financial System and Monetary Policy in an Islamic Economy. JKAU: Islamic Econ., 1, 39-57. https://doi.org/10.4197/islec.1-1.2

Nienhaus, V. (1983). Profitability of Islamic PLS Banks Competing with Interest Banks: Problems and Prospects. J. Res. Islamic Econ, 1(1), 31-39.

Rahman, A. R. (2007). Islamic Banking and Finance : Between Ideals and Realities. IIUM Journal of Economics and Management, 15(2), 123-141.

Shinsuke, N. (2007). Beyond the Theoretical Dichotomy in Islamic Finance:Analytical Reflections on Murābahahah Contracts and Islamic Debt Securities. Kyoto Bulletin of Islamic Area Studies, 1-2, 72-91.

Yusoff, L. M., Rahman, A. A., \& Alias, N. (2001). Interest Rate and Loan Supply: Islamic Versus Conventional Banking System. Jurnal Ekonomi Malaysia, 35, 61-68.

Zainol, Zairy \& Kassim, Salina (2010) An Analysis of Islamic Banks' Exposure to Rate of Return Risk. Journal of Economic Cooperation and Development, 31(1), 59-84.

Zuhaily, W. (1985). Al-Fiqhul Islamy wa Adillatuhu (2nd ed., Vol. 4). Damsyiq, Syria: Darul Fikry. 


\section{Appendix}

Table 3. VAR lag order selection criteria for equation 8

\begin{tabular}{ccccccc}
\hline Lag & LogL & LR & FPE & AIC & SC & HQ \\
\hline 0 & $-2735,173$ & NA & $5,16 \mathrm{E}+22$ & 72,16245 & 72,37712 & 72,24824 \\
1 & $-2303,766$ & 771,9915 & $2.21 \mathrm{e}+18^{*}$ & 62,09911 & $63.81649^{*}$ & $62.78545^{*}$ \\
2 & $-2273,614$ & 48,40154 & $3,74 \mathrm{E}+18$ & 62,59511 & 65,8152 & 63,88202 \\
3 & $-2238,799$ & 49,47457 & $5,91 \mathrm{E}+18$ & 62,96839 & 67,69119 & 64,85585 \\
4 & $-2172,482$ & $82.02344^{*}$ & $4,42 \mathrm{E}+18$ & 62,51268 & 68,7382 & 65,0007 \\
5 & $-2119,764$ & 55,49247 & $5,36 \mathrm{E}+18$ & 62,41485 & 70,14307 & 65,50342 \\
6 & $-2055,553$ & 55,76212 & $5,81 \mathrm{E}+18$ & 62,01456 & 71,24549 & 65,70368 \\
7 & $-1986,224$ & 47,43561 & $7,42 \mathrm{E}+18$ & 61,47959 & 72,21323 & 65,76927 \\
8 & $-1900,24$ & 42,99219 & $1,01 \mathrm{E}+19$ & $60.50631^{*}$ & 72,74266 & 65,39655 \\
\hline * indicates lag order selected by the criterion
\end{tabular}

Table 4. VAR lag order selection criteria for equation 9

\begin{tabular}{ccccccc}
\hline Lag & LogL & LR & FPE & AIC & SC & HQ \\
\hline 0 & $-1977,601$ & NA & $1,89 \mathrm{E}+15$ & 52,20004 & 52,38404 & 52,27358 \\
1 & $-1608,733$ & 669,7877 & $2.97 \mathrm{e}+11^{*}$ & 43,44034 & $44.72837 *$ & $43.95510^{*}$ \\
2 & $-1580,978$ & 46,01495 & $3,75 \mathrm{E}+11$ & 43,65731 & 46,04938 & 44,6133 \\
3 & $-1559,282$ & 32,54324 & $5,71 \mathrm{E}+11$ & 44,03374 & 47,52984 & 45,43096 \\
4 & $-1516,839$ & 56,9637 & $5,26 \mathrm{E}+11$ & 43,86418 & 48,46431 & 45,70261 \\
5 & $-1464,06$ & $62.50148^{*}$ & $3,93 \mathrm{E}+11$ & 43,42262 & 49,12679 & 45,70228 \\
6 & $-1433,16$ & 31,71319 & $5,71 \mathrm{E}+11$ & 43,55683 & 50,36503 & 46,27772 \\
7 & $-1396,669$ & 31,68933 & $8,12 \mathrm{E}+11$ & 43,54392 & 51,45615 & 46,70603 \\
8 & $-1338,628$ & 41,23936 & $7,89 \mathrm{E}+11$ & $42.96390 *$ & 51,98016 & 46,56724 \\
\hline * indicates lag order selected by the criterion
\end{tabular}

Table 5. Pearson correlation results for equation 8

\begin{tabular}{|c|c|c|c|c|c|c|c|c|}
\hline \multicolumn{2}{|c|}{ Variable / Correlation } & \multirow{2}{*}{$\frac{\text { IBFinTot }}{1}$} & \multirow{2}{*}{$\begin{array}{c}\text { IBDepTot } \\
.995^{* *}\end{array}$} & \multirow{2}{*}{$\begin{array}{c}\text { PSRibfintot } \\
-.736^{* *}\end{array}$} & \multirow{2}{*}{$\begin{array}{c}\text { CBRwc } \\
-.399 * *\end{array}$} & \multirow{2}{*}{$\begin{array}{c}\text { IMMR } \\
-.383^{* *}\end{array}$} & \multirow{2}{*}{$\begin{array}{c}\text { CPI } \\
0.178\end{array}$} & \multirow{2}{*}{$\begin{array}{c}\text { IPI } \\
-0.016\end{array}$} \\
\hline IBFinTot & Pearson Correlation & & & & & & & \\
\hline & Sig. (2-tailed) & & 0 & 0 & 0 & 0 & 0.107 & 0.886 \\
\hline \multirow[t]{2}{*}{ IBDepTot } & Pearson Correlation & $.995^{* *}$ & 1 & $-.751 * *$ & $-.391 * *$ & $-.397^{* *}$ & 0.155 & -0.019 \\
\hline & Sig. (2-tailed) & 0 & & 0 & 0 & 0 & 0.162 & 0.861 \\
\hline \multirow[t]{2}{*}{ PSRibfintot } & Pearson Correlation & $-.736 * *$ & $-.751 * *$ & 1 & $.681 * *$ & $.650^{* *}$ & $-.521 * *$ & 0.057 \\
\hline & Sig. (2-tailed) & 0 & 0 & & 0 & 0 & 0 & 0.605 \\
\hline \multirow[t]{2}{*}{ CBRwc } & Pearson Correlation & $-.399 * *$ & $-.391 * *$ & $.681^{* *}$ & 1 & $.720^{* *}$ & $-.738 * *$ & -0.031 \\
\hline & Sig. (2-tailed) & 0 & 0 & 0 & & 0 & 0 & 0.783 \\
\hline \multirow[t]{2}{*}{ IMMR } & Pearson Correlation & $-.383 * *$ & $-.397 * *$ & $.650^{* *}$ & $.720 * *$ & 1 & $-.527 * *$ & -0.041 \\
\hline & Sig. (2-tailed) & 0 & 0 & 0 & 0 & & 0 & 0.712 \\
\hline \multirow[t]{2}{*}{ CPI } & Pearson Correlation & 0.178 & 0.155 & $-.521 * *$ & $-.738 * *$ & $-.527^{* *}$ & 1 & 0.009 \\
\hline & Sig. (2-tailed) & 0.107 & 0.162 & 0 & 0 & 0 & & 0.938 \\
\hline \multirow[t]{2}{*}{ IPI } & Pearson Correlation & -0.016 & -0.019 & 0.057 & -0.031 & -0.041 & 0.009 & 1 \\
\hline & Sig. (2-tailed) & 0.886 & 0.861 & 0.605 & 0.783 & 0.712 & 0.938 & \\
\hline
\end{tabular}

**. Correlation is significant at the 0.01 level (2-tailed). 
Table 6. Pearson correlation results for equation 9

\begin{tabular}{cccccccc}
\hline \multicolumn{2}{c}{ Variable / Correlation } & MuraFin & PSRmurafin & CBRc & IMMR & CPI & IPI \\
\hline \multirow{2}{*}{ MuraFin } & Pearson Correlation & 1 & $-.741^{* *}$ & $-.609^{* *}$ & $-.380^{* *}$ & 0.194 & -0.017 \\
& Sig. (2-tailed) & & 0 & 0 & 0 & 0.079 & 0.88 \\
PSRmurafin & Pearson Correlation & $-.741^{* *}$ & 1 & $.408^{* *}$ & $.423^{* *}$ & $-.356^{* *}$ & 0.072 \\
& Sig. (2-tailed) & 0 & & 0 & 0 & 0.001 & 0.517 \\
CBRc & Pearson Correlation & $-.609^{* *}$ & $.408^{* *}$ & 1 & $.497^{* *}$ & $-.437^{* *}$ & 0.039 \\
& Sig. (2-tailed) & 0 & 0 & & 0 & 0 & 0.722 \\
IMMR & Pearson Correlation & $-.380^{* *}$ & $.423^{* *}$ & $.497^{* *}$ & 1 & $-.527^{* *}$ & -0.041 \\
& Sig. (2-tailed) & 0 & 0 & 0 & & 0 & 0.712 \\
\multirow{2}{*}{ CPI } & Pearson Correlation & 0.194 & $-.356^{* *}$ & $-.437 * *$ & $-.527 * *$ & 1 & 0.009 \\
& Sig. (2-tailed) & 0.079 & 0.001 & 0 & 0 & & 0.938 \\
IPI & Pearson Correlation & -0.017 & 0.072 & 0.039 & -0.041 & 0.009 & 1 \\
& Sig. (2-tailed) & 0.88 & 0.517 & 0.722 & 0.712 & 0.938 & \\
\hline
\end{tabular}

**. Correlation is significant at the 0.01 level (2-tailed).

Table 7. Variance Decomposition (VDC) for equation 8

\begin{tabular}{ccccccccc}
\hline & \multicolumn{7}{c}{ Variance Decomposition of DCBR_WC: } \\
Period & S.E. & DIBFINTOT & DIBDEPTOT & DPSR_IBFINTOT & DIMMR & DCBR_WC & CPI & IPI \\
\hline 1 & 0.198435 & 0.244824 & 0.424316 & 4.227 .381 & 0.839607 & 9.426 .387 & 0.000000 & 0.000000 \\
2 & 0.266482 & 0.746083 & 0.303217 & 4.376 .517 & 3.192 .784 & 9.131 .642 & 0.027978 & 0.036999 \\
3 & 0.312494 & 1.280 .927 & 0.224429 & 4.945 .303 & 6.153 .405 & 8.728 .137 & 0.063242 & 0.051329 \\
4 & 0.347598 & 1.815 .320 & 0.184949 & 5.798 .903 & 9.189 .409 & 8.282 .873 & 0.103595 & 0.079091 \\
5 & 0.376051 & 2.311 .706 & 0.176688 & 6.779 .536 & 1.204 .626 & 7.842 .784 & 0.148104 & 0.109869 \\
6 & 0.399844 & 2.757 .590 & 0.189613 & 7.787 .465 & 1.459 .529 & 7.433 .414 & 0.192893 & 0.143007 \\
7 & 0.420043 & 3.149 .885 & 0.214956 & 8.753 .318 & 1.679 .811 & 7.067 .200 & 0.236051 & 0.175680 \\
8 & 0.437290 & 3.491 .556 & 0.246150 & 9.639 .088 & 1.866 .314 & 6.747 .718 & 0.276296 & 0.206586 \\
9 & 0.452030 & 3.787 .902 & 0.278798 & 1.042 .782 & 2.022 .165 & 6.473 .583 & 0.313100 & 0.234900 \\
10 & 0.464603 & 4.044 .864 & 0.310203 & 1.111 .620 & 2.151 .280 & 6.240 .928 & 0.346344 & 0.260317 \\
\hline
\end{tabular}

Table 8. Variance Decomposition (VDC) for equation 9

\begin{tabular}{cccccccc}
\hline & \multicolumn{9}{c}{ Variance Decomposition of DCBR_C: } & & \\
Period & S.E. & DMURAFIN & DPSR_MURAFIN & DIMMR & DCBR_C & CPI & IPI \\
\hline 1 & 0.436267 & 0.660376 & 0.116404 & 0.022559 & 9.920 .066 & 0.000000 & 0.000000 \\
2 & 0.550970 & 0.655741 & 0.221721 & 0.136801 & 9.865 .342 & 0.100333 & 0.231980 \\
3 & 0.608580 & 0.662833 & 0.284134 & 0.502680 & 9.818 .660 & 0.138062 & 0.225685 \\
4 & 0.641522 & 0.693628 & 0.292691 & 0.983208 & 9.763 .059 & 0.159519 & 0.240363 \\
5 & 0.661422 & 0.730035 & 0.285681 & 1.526 .790 & 9.702 .928 & 0.181002 & 0.247214 \\
6 & 0.674067 & 0.769286 & 0.275961 & 2.082 .115 & 9.641 .935 & 0.199735 & 0.253557 \\
7 & 0.682457 & 0.808220 & 0.269621 & 2.618 .529 & 9.582 .847 & 0.216784 & 0.258376 \\
8 & 0.688261 & 0.845608 & 0.268093 & 3.116 .454 & 9.527 .578 & 0.231890 & 0.262176 \\
9 & 0.692436 & 0.880808 & 0.270907 & 3.566 .096 & 9.477 .189 & 0.245188 & 0.265107 \\
10 & 0.695547 & 0.913635 & 0.276987 & 3.964 .288 & 9.432 .093 & 0.256800 & 0.267364 \\
\hline
\end{tabular}

\section{Copyrights}

Copyright for this article is retained by the author(s), with first publication rights granted to the journal.

This is an open-access article distributed under the terms and conditions of the Creative Commons Attribution license (http://creativecommons.org/licenses/by/4.0/). 